\title{
DAMPAK SOSIAL EKONOMI TEMPAT PEMBUANGAN AKHIR (TPA) BAGI PEMULUNG DESA MRICAN PONOROGO
}

\author{
Muhammad Siregar ${ }^{1}$, Robby Darwis Nasution² \\ ${ }^{1}$ Fakultas Ilmu Sosial dan Ilmu Politik, Universitas Muhammadiyah Ponorogo, Jawa Timur \\ Email : Mohammadsiregar27@gmail.com \\ ${ }^{2}$ Fakultas Ilmu Sosial dan Ilmu Politik, Universitas Muhammadiyah Ponorogo, Jawa Timur \\ Email :Darwisnasution69@gmail.com
}

Masuk : 16-04-2020, revisi: 30-04-2020, diterima untuk diterbitkan : 30-04-2020

\begin{abstract}
Growth in population and settlements in Ponorogo resulted more garbage. Landfill in Mrican is located adjacent to the residential area. This gives rise to various impacts. Analysis of the impacts on socio-economic is needed. The analysis has been carried out to reduce the risk of landfills. This study aims to: (i) analyze the impact of landfills on scavengers, (ii) analyze the efforts of scavengers on the impacts caused by landfills. This research used a qualitative methods with a fenomenology approach. Collecting data and information related to the impact of landfills on scavengers and waste adaptation strategies to these impacts is carried out by observation, in-depth interviews and literature studies. Data analysis used descriptive qualitative techniques. Result showed that Mrican landfills provide job opportunities, supplementing income for daily needs and education costs. Parents who has involved children to scavenge can hamper children's education. Scavengers in meeting the needs of clean water is to consume PDAM water. While the future period of effort in maintaining the life of scavengers is to add a side business that is by farming and raising livestock.
\end{abstract}

Keywords: Waste, landfill, scavengers, impact analysis, socio economic.

\begin{abstract}
ABSTRAK
Pertumbuhan jumlah penduduk dan permukiman di Kota Ponorogo mengakibatkan jumlah sampah semakin banyak. Fakta menunjukkan bahwa tempat pembuangan akhir sampah di Mrican terletak berdampingan dengan kawasan permukiman. Hal ini menimbulkan berbagai dampak sehingga dibutuhkan analisis mengenai dampak terhadap sosial ekonomi. Analisis dilakukan untuk mengurangi resiko yang ditimbulkan dari keberadaan tempat pembuangan akhir sampah. Penelitian ini bertujuan untuk: (i) menganalisis dampak tempat pembuangan akhir sampah terhadap pemulung, (ii) menganalisis upaya pemulung terhadap dampak yang ditimbulkan oleh tempat pembuangan akhir sampah. Penelitian ini menggunakan metode kualitatif dengan pendekatan fenomenologi. Pengumpulan data dan informasi terkait dampak tempat pembuangan akhir sampah terhadap pemulung serta strategi adaptasi pemulung terhadap dampak tersebut dilakukan dengan teknik observasi, wawancara mendalam dan studi literatur. Analisis data menggunakan teknik deskriptif kualitatif. Hasil penelitian menunjukkan tempat pembuangan akhir sampah Mrican memberi peluang kerja, menambah penghasilan untuk kebutuhan sehari-hari dan biaya pendidikan. Orang tua yang melibatkan anak untuk memulung dapat menghambat pendidikan anak. Pemulung memanfaatkan air PDAM di sekitar tempat tinggalnya untuk pemenuhan kebutuhan air bersih. Upaya jangka waktu ke depan dalam mempertahankan kehidupan pemulung dilakukan dengan bekerja sampingan yaitu dengan bercocok tanam dan beternak.
\end{abstract}

Kata Kunci : Sampah, TPA, pemulung, analisa dampak, sosial ekonomi.

\section{PENDAHULUAN}

\section{Latar belakang}

Indonesia merupakan salah satu negara yang memiliki penduduk sangat besar dan memiliki kecenderungan meningkat dari waktu ke waktu. Kenaikan jumlah penduduk akan mengakibatkan bertambahnya volume sampah yang dihasilkan terutama di daerah perkotaan. Peningkatan jumlah tumpukan sampah secara tidak langsung menimbulkan dampak negatif. Ditinjau dari segi keseimbangan lingkungan, kesehatan, keamanan dan pencemaran, apabila sampah tidak dikelola dengan baik dapat menimbulkan berbagai gangguan. Secara estetika 
sampah tidak dapat digolongkan sebagai pemandangan yang nyaman untuk dinikmati (Hadiwiyoto, 1983).

Namun jika sampah dikelola dengan baik akan menimbulkan dampak positif seperti peningkatan kesejahteraan masyarakat. Hal tersebut dapat terjadi karena pengelolaan sampah mendukung penyerapan tenaga kerja, terbukanya lapangan pekerjaan baru, manfaat ekonomi dari pengolahan sampah, dan perbaikan kualitas lingkungan yang secara tidak langsung terjadi. Pemerintah telah melakukan upaya dalam menanggulangi kerusakan dan bahaya yang diakibatkan oleh sampah melalui penyediaan Tempat Pembuangan Akhir (TPA) sampah. Mahyudin (2017) menyatakan TPA merupakan sarana fisik berakhirnya suatu proses untuk menyimpan dan memusnahkan sampah dengan cara tertentu sehingga dampak negatif yang ditimbulkan kepada lingkungan dapat dikurangi.

Produksi limbah padat dari pusat populasi dengan kepadatan tinggi menciptakan masalah dalam manajemen suatu kota (Hasan \& Mulamoottil, 1994). Pemerintah, masyarakat, dunia usaha dan para pakar diharapkan dapat melahirkan ide segar yang dapat diterapkan guna menyelesaikan persoalan perkotaan mulai dari pengangguran, kemiskinan, polusi, persampahan dan lainnya di Indonesia. Selain memiliki potensi bencana, sampah juga memiliki potensi ekonomi yang besar. Potensi ekonomi dari daur ulang sampah yaitu sebagai bahan baku industri. Keuntungan secara ekonomi dapat dilihat dari banyaknya pemanfaat (user) di tempat pembuangan akhir sampah. Pemanfaat diantaranya pemulung, pengepul, dan penggiling yang bekerja secara informal.

Peningkatan jumlah penduduk, ekonomi, kesejahteraan, pola konsumsi, pola keamanan dan perilaku penduduk, aktivitas fungsi kota, kepadatan penduduk dan bangunan, serta kompleksitas problem transportasi menjadi pendukung munculnya permasalahan sampah di perkotaan. Sampah menjadi sumber penyakit, dan merusak estetika kota. Salah satu cara penanggulangan yang paling mudah adalah membuang sampah di suatu tempat yang jauh dari pemukiman. Tempat pembuangan sampah secara teknis disebut sebagai TPA (Mahyudin, 2017).

Kota Ponorogo juga tidak terlepas dari masalah sampah. Penduduk yang padat dengan segala aktivitasnya menghasilkan sampah yang banyak. Permasalahan muncul dengan keterbatasan luas wilayah Kota Ponorogo yang tidak memungkinkan membuang sampah di wilayah sendiri. Solusinya adalah bekerja sama dengan Dinas Lingkungan Hidup menjadikan lahan di Desa Mrican Dukuh Klego Kecamatan Jenangan sebagai TPA sampah.

Tempat Pembuangan Akhir Mrican secara administratif berada di Kota Ponorogo. TPA sampah Mrican secara fungsional merupakan tempat pembuangan sampah yang berasal dari kota Ponorogo. Pengelolaan sampah dilakukan oleh Dinas Lingkungan Hidup. TPA Mrican menampung sampah yang berasal dari berbagai tempat di Ponorogo. TPA ini memiliki luas sebesar 2,7 ha, zona pembuangan TPA sampah Mrican setiap hari menampung kurang lebih 30 truk. Sampah untuk sebagian orang dianggap barang yang tidak memiliki nilai ekonomis.

Namun para pemulung sampah di TPA Mrican melihat masih terdapat potensi ekonomi dari sampah yang sebagian masyarakat menganggap tidak ada manfaatnya. Keberadaan mereka di Mrican adalah untuk mengambil manfaat ekonomi. Selain itu juga bermanfaat untuk lingkungan, yaitu dengan mengumpulkan plastik, kaca, dan logam yang sulit diurai secara alamiah. Secara tidak langsung keberadaan pemulung dan pemanfaat di TPA Mrican membantu 
mengurangi (reduce) volume sampah terutama sampah yang sulit terurai. Berdasarkan paparan di atas menunjukkan bahwa keberadaan TPA sampah menimbulkan berbagai tanggapan dari masyarakat sekitar. Demikian pula dengan TPA sampah di Desa Mrican Kecamatan Jenangan Kabupaten Ponorogo yang dapat menimbulkan dampak sosial dan ekonomi. TPA sampah di Desa Mrican Kecamatan Jenangan Kabupaten Ponorogo telah beroperasi sejak tahun 1995.

Studi pendahuluan yang dilakukan peneliti menunjukkan bahwa TPA sampah menimbulkan permasalahan pada masyarakat diantaranya sering menimbulkan bau yang tidak sedap akibat penumpukan sampah dan adanya truk-truk pengangkut sampah yang sering tidak ditutup, sehingga cairan lindi berceceran di sepanjang jalan menuju TPA. Hal ini tentunya menimbulkan bau sampah di sepanjang jalan tersebut. Namun demikian, peneliti sering melihat pemulung dan pengepul sibuk dengan sampah di TPA. Peneliti tertarik meneliti tentang tanggapan pemulung terhadap potensi sosial ekonomi dari Tempat Pembuangan Akhir (TPA) sampah di Desa Mrican Kecamatan Jenangan Kabupaten Ponorogo. Selain itu, menurut informasi warga setempat belum pernah dilakukan penelitian sebelumnya di Desa Mrican Kecamatan Jenangan Kabupaten Ponorogo tentang potensi sosial ekonomi dalam keberadaan TPA.

Berdasarkan identifikasi masalah yang telah dilakukan, maka rumusan masalah dalam penelitian ini adalah bagaimana dampak keberadaan tempat pembuangan akhir (TPA) terhadap kondisi sosial ekonomi pemulung Desa Mrican Kabupaten Ponorogo ?

\section{METODE PENELITIAN}

Penelitian ini menggunakan metode kualitatif dengan pendekatan deskriptif kualitatif. Lokasi penelitian dilakukan pada TPA sampah Mrican. Teknik pengumpulan data yang digunakan dalam penelitian ini adalah wawancara, observasi dan dokumentasi. Informan yang dimaksud dalam penelitian ini adalah orang-orang yang benar- benar mengetahui dan terlibat langsung dengan fokus permasalahan. Informan memberikan keterangan mengenai fakta-fakta atau kenyataan sebenarnya yang terjadi tentang potensi sosial ekonomi masyarakat dalam keberadaan TPA Mrican. Penelitian ini melibatkan empat orang pemulung sampah yang dipilih dari sepuluh pemulung yang beraktivitas di TPA sampah Mrican, tiga aparat desa dan dua masyarakat sekitar TPA Mrican.Teknik pemilihan informan adalah teknik purposive sampling dengan informan yang dipilih yaitu Kepala Desa, Perangkat Desa, Masyarakat, Pemulung.

\section{HASIL DAN PEMBAHASAN}

\section{Analisis dampak keberadaan TPA terhadap sosial ekonomi pemulung}

Desa Mrican termasuk daerah agraris. Sebagian besar penduduk bermata pencaharian sebagai petani atau bekerja di bidang pertanian. Bidang pertanian diprioritaskan untuk meningkatkan perekonomian masyarakat. Sebagian komoditas sudah meningkat, akan tetapi harga hasil produksi relatif masih rendah, sehingga pendapatan petani rendah. Selain itu jumlah pengangguran masih cukup tinggi terutama pada masa setelah tanam dan panen.

Dengan adanya Tempat Pembuangan Akhir (TPA) sampah di Desa Mrican terdapat dampak positif bagi masyarakat sekitar yang kurang mampu. Pola pikir masyarakat sekitar berubah. Sebagian masyarakat beralih menjadi pemulung. Profesi pemulung diminati masyarakat karena cepat dan mudah mendapatkan hasil dan keuntungan untuk memenuhi berbagai kebutuhan hidup. Profesi ini membutuhkan kekuatan tenaga tanpa keahlian tertentu. Daya pikir yang terbatas mendorong manusia melakukan pekerjaan dengan mementingkan proses yang diinginkan. Namun banyak juga yang mementingkan hasil sebagai tujuan utama dalam 
melakukan sebuah pekerjaan. Persoalan kebutuhan kehidupan menjadi alasan pilihan pekerjaan tertentu (Toonies, 1887/2001).

Para pemulung melakukan aktivitas memungut atau mengumpulkan barang bekas (sampah) yang dapat dimanfaatkan kembali atau dijual. Mereka menjadikan TPA sampah sebagai ladang mata pencarian baru. Salah satu penyebab seseorang menjadi pemulung adalah faktor kebutuhan rumah tangga. Bapak Trm, (53 tahun), menjadi pemulung karena beban dan tanggungan memberi nafkah keluarga serta biaya sekolah anak-anaknya. Profesi pemulung memungkinkan kemudahan dalam mendapatkan uang untuk memenuhi kebutuhan. Sebagaimana dengan pemulung ibu Ktn, selama 25 tahun menjadi pemulung di TPA sampah Desa Mrican. Ibu Ktn menjalankan pekerjaan memulung di TPA sampah, dengan alasan bahwa pekerjaannya mudah dikerjakan dan tidak memerlukan keahlian. Dengan memulung ibu Ktn dapat mencari sayuran bekas untuk makanan kambing. Selain itu juga mencari rosokan barang plastik, karton, besi, tembaga, kuningan, dan logam bekas lainnya untuk dijual ke pengepul.

APS (Kepala Desa) mengganggap perekonomian masyarakat sekitar bisa terbantu. Masyarakat sekitar kebanyakan tidak mempunyai pekerjaan. Maka dengan adanya TPA sampah mereka dapat mencari pakan untuk hewan peliharaan dan mencari barang bekas yang bisa dijual. Myn (ketua RT) berpendapat bahwa dengan adanya TPA sampah warga sekitar yang kurang mampu bisa mendapatkan nafkah. Sedangkan Hkm (warga masyarakat) berpendapat bahwa bagi masyarakat yang kurang mampu memulung di TPA sampah bisa dijadikan pekerjaan sampingan, karena mereka mencari rosok dan juga pakan ternak. Dengan demikian Tempat Pembuangan Akhir (TPA) sampah Desa Mrican memberikan dampak positif dari segi peluang kerja bagi pemulung, yaitu sebagai mata pencarian untuk meningkatkan perekonomian terutama para pemulung yang mencari rejeki di TPA sampah.

Pemulung tidak hanya mencari sampah yang mempunyai nilai ekonomis seperti barang plastik, karton, besi, tembaga, kuningan dan logam bekas lainnya tetapi juga sampah seperti sayuran yang berguna untuk makanan ternak. Sebagian besar pemulung berasal dari masyarakat sekitar TPA sampah. Secara ekonomis pendapatan pemulung di TPA Mrican didapatkan dari pengumpulan sampah dan menjualnya ke pengepul. Menurut APS (Kepala Desa), dengan mengumpulkan sampah maka warga sekitar yang tidak mempunyai pekerjaan dapat mencari barang bekas kemudian dijual atau untuk makanan ternak. Pendapat senada dikemukakan oleh Ayd (Kepala Dusun Klego) dengan adanya TPA sampah dapat mengangkat perekonomian masyarakat sekitar juga memberi penghasilan tambahan. Pemulung juga mempunyai sawah dan ternak seperti kambing dan sapi.

Masyarakat yang menggantungkan sumber penghasilannya pada TPA sampah menolak pemindahan TPA. Ketua Rukun Tetangga (RT), bapak Myn menyatakan bahwa bagi warga masyarakat TPA sampah menjadi sumber penghasilan dan membuka lowongan pekerjaan bagi masyarakat yang tidak mempunyai mata pencaharian. Penghasilan rata-rata berkisar antara Rp. 30.000 hingga Rp. 50.000. Penghasilan tersebut digunakan untuk kehidupan keluarga. Sumber penghasilan lainnya dari penjualan sampah plastik dan bahan yang mempunyai nilai ekonomis. Selain itu para pemulung juga mendapat keuntungan dari sampah sayuran bekas untuk pakan ternak. Penghasilan tergantung juga dengan beberapa faktor salah satunya yaitu kapan mereka harus mengumpulkan barang-barang bekas, memilah-milah hasil pulungan dan menentukan kapan mereka harus istirahat. Menurut Hkm (warga masyarakat sekitar) dengan adanya TPA sampah dapat meningkatkan perekonomian masyarakat yang sudah berumur dan belum mempunyai pekerjaan tetap. 
Sebagian besar pemulung di TPA sampah Mrican, memiliki latar belakang pendidikan yang rendah yakni tidak tamat Sekolah Dasar (SD) dan sebagian kecil hanya sampai jenjang Sekolah Menengah Pertama (SMP). Penghasilan sebagai pemulung di TPA sampah Mrican, cukup untuk membayar uang sekolah. Penghasilan dapat bertambah jika diikutsertakan anggota keluarga, biasanya anak untuk memulung. Uang mudah didapat dan langsung setiap harinya. Akibatnya, anak-anak yang diikutsertakan memulung menjadi malas berpikir dan berusaha. Mereka beranggapan pendidikan tidak penting.

Menurut Gunawan (2000) sekolah adalah salah satu tempat untuk mendidik anak. Selain itu pendidikan anak berlangsung di rumah dan di masyarakat. Orangtua wajib memperhatikan, menyayangi, dan melayani anak di rumah. Dengan demikian orangtua yang melibatkan anak untuk memulung dapat menghambat pendidikan anak. Hal ini menunjukan bahwa, dinas pendidikan perlu lebih aktif melakukan sosialisasi tentang pentingnya pendidikan sehingga anak-anak pemulung memiliki motivasi yang besar untuk melanjutkan pendidikan yang lebih tinggi.

Ketika penelitian dilakukan, sejauh ini penulis belum menemukan adanya gangguan penyakit yang diderita pemulung sebagai dampak dari pekerjaannya. Suatu studi di Manila menunjukkan setidaknya terdapat 35 jenis penyakit yang mudah berjangkit di dalam komunitas pemulung (Aida, Firuza, \& Fauziah, 2011). Penyakit-penyakit tersebut termasuk diare, demam tifoid, kolera, disentri, TBC, antraks, poliomielitis, gangguan kulit, pneumonia dan malaria (Haskarlianus, Graham, \& Guntur, 2007). Risiko kesehatan kerja juga terlihat di antara komunitas pemulung. Risiko kesehatan tersebut bersumber dari sampah yang terjadi ketika mengumpulkan, memproses, mendaur ulang dan membuang sampah (Fauziah, Simon \& Agamuthu, 2004).

Sebagian besar waktu pemulung dihabiskan untuk mengais sampah. Tidak ada aktivitas lain untuk berhenti dari pekerjaannya. Kondisi fisik seseorang secara umum membutuhkan istirahat mengembalikan kekuatan dan tenaga yang telah terkuras. Kesehatan fisik vital untuk bekerja di TPA sampah. Para pemulung lebih mementingkan keuntungan dari hasil penjualan sampah. Pemulung telah abai akan bahaya dan risiko kesehatan dalam kehidupan sehari-hari. Dengan demikian, pihak berwenang harus memiliki kebijakan dan peraturan yang lebih baik dalam pengelolaan TPA sampah sehubungan dengan keterlibatan pemulung.

Dampak negatif lainnya dari keberadaan TPA sampah Mrican adalah terganggunya saluran pengairan persawahan. Pada musim penghujan, banyak sampah terbawa derasnya air sehingga menggangu saluran pengairan ke sawah yang berada di sekitar TPA sampah Mrican. Dalam hal keperluan untuk sumber air minum, para pemulung tidak terganggu karena masyarakat sekitar TPA Mrican menggunakan air dari perusahaan daerah air minum (PDAM).

Dampak lainnya dari keberadaan TPA bahwa masyarakat yang bermukim di sekitar TPA sampah Mrican sebagian besar merasa terganggu oleh bau sampah yang ditimbulkan pada waktu musim penghujan. Sejauh ini masyarakat tidak mengalami gangguan pernapasan yang diderita. Pada musim hujan bau yang ditimbulkan sampai sekitar pemukiman. Dampak lainnya, bahwa jalanan menjadi kotor, karena sampah yang tercecer dari truk pembawa sampah. 


\section{Upaya dalam mengatasi masalah sosial ekonomi pemulung di TPA sampah Mrican}

Upaya adalah kemampuan seseorang dalam menyelesaikan masalah yang mencakup kehidupannya. Upaya juga berarti usaha, akal, ikhtiar untuk mencapai suatu maksud, memecahkan persoalan mencari jalan keluar. Pada dasarnya upaya dilakukan untuk mengurangi resiko yang terjadi terhadap unsur-unsur rentan terhadap dampak fenomena tertentu. Upaya seseorang berbeda-beda tergantung pada kondisi sosial ekonomi, pengetahuan, dan pengalaman yang dimiliki dalam menghadapi kondisi lingkungan tempat mereka beradaptasi.

Pemulung sekitar TPA sampah Mrican berupaya untuk meningkatkan ekonomi, berusaha menambah jumlah ternak yang dimiliki. Pemulung memanfaatkan banyakya sampah sayuran di TPA sampah. Selain itu, mereka memilah sampah yang mempunyai nilai ekonomis lebih seperti barang plastik, karton, besi, tembaga, kuningan dan logam bekas lainnya. Bertambahnya volume sampah mendorong pemulung bekerja lebih keras. Mereka menambah jam kerja untuk mengumpulkan sampah yang bernilai jual lebih banyak. Upaya ke depan dilakukan untuk mencari jalan keluar agar tidak menjadi pemulung yaitu dengan bercocok tanam dan mencari pekerjaan sampingan seperti beternak.

Kegiatan menyesuaikan diri dengan keadaan melalui tindakan nyata dilakukan untuk mengurangi dampak keterpurukan ekonomi. Para pemulung melakukan kegiatannya dengan menambah jam kerja dalam mencari sampah dan memilah sampah yang mempunyai nilai jual lebih. Selain itu, mencari usaha sampingan yaitu bercocok tanam di sawah dan juga beternak karena banyak sayuran bekas di tempat sampah. Upaya tersebut merupakan proyeksi karakteristik pemulung dengan ketidakpedulian yang tinggi karena kemiskinan dan tingkat pendidikan rendah.

\section{Kehidupan sosial ekonomi pemulung dengan masyarakat di Desa Mrican.}

Kehidupan sosial adalah kehidupan yang meliputi unsur-unsur sosial/kemasyarakatan. Sebuah kehidupan disebut sebagai kehidupan sosial jika ada interaksi antara individu satu dengan individu lainnya, dan terjadi komunikasi dan interaksi yang kemudian berkembang dan saling membutuhkan kepada sesama. Kehidupan sosial merupakan kehidupan yang ditandai dengan adanya unsur-unsur sosial kemasyarakatan itulah yang disebut kehidupan sosial. Di dalam kehidupan sosial, idealnya kita akan menemukan sebuah interaksi sosial. Kegiatan sosial antara lain berupa kegiatan-kegiatan sosial kemasyarakatan seperti gotong royong, kerja bakti, tolongmenolong, dan berpartisipasi dalam kegiatan tertentu. Kegiatan sosial sifatnya saling membutuhkan antara satu mahluk hidup dengan yang lainnya. Dengan demikian harus terus di dijaga agar tercipta rasa aman dan tidak ada kesenjangan sosial. Kehidupan sosial merupakan kondisi atau keadaan masyarakat yang di dalamnya terdapat unsur sosial seperti interaksi antar satu dengan yang lain, dan hubungan masyarakat yang satu dengan masyarakat yang lain (Hasannudin, 2016).

Kehidupan sosial ekonomi merupakan kedudukan atau posisi seseorang dalam kelompok manusia yang ditentukan oleh jenis aktivitas ekonomi, pendapatan, tingkat pendidikan, usia, jenis rumah tinggal, dan jenis jabatan dalam berbagai organisasi, dan sebagainya. Sehingga dapat disimpulkan bahwa status sosial ekonomi menandakan tinggi redahnya kondisi sosial ekonomi dimasyarakat. Indikator yang digunakan yaitu latar belakang pendidikan orang tua, usia, jenis pekerjaan, tingkat pendapatan, kondisi lingkungan, tempat tinggal, pemilikan kekayaan, dan aktivitas kelompok dalam komunitasnya (Abdulsyani, 2007).

Manusia dalam kehidupan sehari-hari walaupun mempunyai kedudukan dan kekayaan tidak dapat hidup sendiri. Manusia selalu membutuhkan keberadaan orang lain untuk berkomunikasi dan bersosialiasi. Faktor yang mendorong manusia sebagai makhluk sosial adalah terjadinya 
interaksi antar manusia. Interaksi ini terdiri dari tiga hal; Pertama, terkait dengan kondisi psikologis yang berasal dari tekanan emosional. Kondisi psikologis memengaruhi interaksi manusia yang memungkinkan manusia menjadi bahagia, senang atau sebaliknya. Kedua, memiliki hasrat yang tinggi dalam berhubungan dengan orang lain ketika kondisi dan harga diri rendah karena ketika merasa direndahkan butuh dukungan moral. Secara psikologis manusia butuh dukungan dan perlindungan agar kembali pada kondisi awal. Ketiga, terisolasi dari komunitas dalam melakukan interaksi dengan orang yang mengerti dan terbentuknya interaksi baru sehingga terjalinnya hubungan yang baik dan harmonis (Muttaqin, 2014). Merujuk pada perkembangan ini, manusia pada hakikatnya merupakan makhluk sosial dan politik yang membentuk hukum dan membentuk kaidah perilaku serta saling bekerja sama. Kemampuan manusia dalam bekerja sama akan bersandar pada kerja sama sosial antar kelompok dan merupakan syarat kehidupan bermasyarakat karena saling membutuhkan.

Kehidupan sosial pemulung sebagai anggota masyarakat sekitar TPA Mrican sangat baik secara sosial, dimana pemulung jika bertemu dengan tetangga atau masyarakat sekitar, akan saling menyapa dan juga selalu senyum dalam menghadapi pekerjaan seberat apapun dan hidup sesusah apapun. Walaupun pemulung ini hidupnya hanya sebatas pemulung akan tetapi, mereka pada setiap acara adat tetap akan berpartisipasi. Hubungan sosial antara masyarakat sekitar dengan masyarakat pemulung terjalin dengan baik. Hubungan baik tersebut tidak hanya terlihat dari segi interaksi saja akan tetapi juga ditandai dengan adanya bantuan-bantuan masyarakat sekitar kepada masyarakat pemulung. Selain itu, pada saat aparat Pemerintah Desa Mrican menghimbau masyarakat agar melakukan gotong royong untuk membersihkan lingkungan, maka baik masyarakat pemulung maupun masyarakat yang bukan pemulung senantiasa bersama-sama, melaksanakan gotong royong seperti yang dihimbau oleh pemerintah wilayah Desa Mrican.

\section{KESIMPULAN DAN SARAN \\ Kesimpulan}

Dampak TPA sampah Mrican bagi pemulung antara lain memberikan peluang kerja sebagai pemulung dan pemilah sampah sehingga memberikan kontribusi penghasilan untuk memenuhi kebutuhan sehari-hari dan biaya sekolah. Pendapatan tiap pemulung berbeda-beda yaitu berkisar antara Rp.30.000 hingga Rp.75.000. Dalam bidang pendidikan orangtua kurang memperhatikan pendidikan anak. Mereka cenderung membiarkan anak-anak turut memulung. Sedangkan dari segi kesehatan, TPA sampah tidak terlalu menimbulkan dampak negatif bagi pemulung dewasa. Mereka menganggap kesehatan bukanlah menjadi prioritas utama. Perhatian mereka lebih terfokus kepada kegiatan yang berhubungan dengan pencarian nafkah. Tumpukan sampah di TPA sampah Mrican menyebabkan terganggunya saluran pengairan ke sawah pada musim penghujan serta menimbulkan bau, lalat, dan asap pembakaran sampah.

Hasil penelitian menunjukkan bahwa upaya bertahan hidup yang dilakukan pemulung untuk memenuhi kebutuhan sehari-hari adalah dengan menambah waktu kerja. Sedangkan upaya pemulung untuk masa yang akan datang adalah mencari usaha sampingan yaitu dengan bercocok tanam dan beternak. Upaya tersebut bertujuan untuk menambah pemasukan agar anak-anak mereka kelak dapat melanjutkan pendidikan ke jenjang yang lebih tinggi.

\section{Saran}

Upaya untuk bertahan hidup pemulung masih tergolong sederhana sehingga perlu dilakukan sosialisasi dari pihak terkait guna meningkatkan perekonomian para pemulung. Perlunya sosialisasi dari instansi terkait seperti dinas pendidikan tentang pentingnya pendidikan sehingga 
anak-anak pemulung memiliki motivasi yang besar untuk melanjutkan pendidikan yang lebih tinggi.

\section{Ucapan Terima Kasih}

Penulis mengucapkan terima kasih kepada para informan, juga perizinan dari Dinas Lingkungan Hidup serta pihak -pihak yang mendukung terlaksananya penelitian ini.

\section{REFERENSI}

Abdulsyani. (2007). Sosiologi skematika teori dan terapan. Jakarta: PT Bumi.

Aida, H. Z., Firuza, B. M., \& Fauziah, S. H. (2011). Socio-Economic Studies of Scavengers in Malaysian Landfills. Prosiding. International Conference On Population Dynamism Of Asia, 11-13 July 2011. University of Malaya. eprints.um.edu.my

Fauziah S. H., Simon, C., \& Agamuthu, P. (2004) Municipal solid waste management in Malaysia - possibility of improvement?. Malaysian Journal of Science, 23(2), 61-70. https://mjs.um.edu.my/article/view/8414/5847

Gunawan, A. H. (2000). Sosiologi pendidikan. Jakarta: PT. Rineka Cipta.

Hardiwiyoto, S. (1983). Penangaan dan pemanfaatan sampah. Jakarta: Yayasan Idayu.

Hasan, S., \& Mulamoottil, G. (1994). Environmental problems of Dhaka city. Cities, I1(3) 195200. doi: https://doi.org/10.1016/0264-2751(94)90059-0

Hasanudin. (2016). Kehidupan sosial pemulung di tempat pembuangan akhir. Skripsi, Universitas Islam Negeri Allaudin Makasar. repositori.uin-alauddin.ac.id

Haskarlianus, P., Graham, A. M., \& Guntur, S. (2007). Neighborhood-based waste management: A solution for solid waste problems in Jakarta, Indonesia. Waste Management, 27, 1924-1938. doi: 10.1016/j.wasman.2006.09.010

Mahyudin, R. P. (2017). Kajian permasalahan pengelolaan sampah dan dampak lingkungan di TPA (tempah pembuangan akhir). Jurnal Tehnik Lingkungan, 3(1), 66 - 74. ppjp.ulm.ac.id > article

Muttaqin, A. (2014). Pola Keberagaman Masyarakat Marginal. Direktur Pusat Studi Agama dan Kebudayaan STAIN Purwokerto, 8(2), 131. ejournal.iainpurwokerto.ac.id

Kementerian Perencanaan Pembangunan Nasional (BAPENAS). (2018). Profil Desa Mrican 2019.

Toonies, F. (2001). Community and civil society. (Jose Harris \& Margaret Hollis, Trans. Karya asli diterbitkan tahun 1887). Cambridge University Press United Kingdom. 